\title{
Analysis of the molecular mechanism of Pudilan (PDL) treatment for COVID-19
}

\author{
qi Kong ${ }^{1}$, Zhiguang Xiang ${ }^{1}$, Yue $\mathrm{Wu}^{1}, \mathrm{Yu} \mathrm{Gu}^{1}$, Jianguo Guo ${ }^{1}$, and Xiuping $\mathrm{Chen}^{2}$ \\ ${ }^{1}$ Chinese Academy of Medical Sciences Institute of Laboratory Animal Sciences \\ ${ }^{2}$ Qingdao University Medical College
}

April 29, 2020

\begin{abstract}
Background and Purpose: Pudilan (PDL), a four-herb prescription with the traditional function of heat-clearing and detoxifying, has been used for anti-SARS-CoV-2 infection, anti-inflammation effect, and clear infection. PDL is one of the therapeutic potentials for COVID-19 while the underlying mechanisms remain to be clarified. Experimental Approach: We used network pharmacology analysis, and selected 68 co-targeted genes/proteins as targets of both PDL and COVID-19. These co-targeted genes/proteins were predicted by SwissDock Server for their high-precision docking simulation, and analyzed by STRING for proteins to protein interaction (PPI), pathway and GO (gene ontology) enrichment. WebGestalt (WEB-based Gene SeT AnaLysis Toolkit) was used for gene set enrichment analysis (GSEA) for functions and pathways enrichment. The therapeutic effect for PDL treatment on COVID-19 was validated by the TCMATCOV (TCM Anti COVID-19) platform. Key Results: PDL may prevent the entrance of SARS-CoV-2 entry into cells by blocking the angiotensin-converting enzyme 2 (ACE2). It may inhibit the cytokine storm by affecting C-reactive protein (CRP), interferon- $\gamma$ (IFN- $\gamma$ ), interleukin- 6 (IL-6), interleukin10 (IL-10), tumor necrosis factor (TNF), epidermal growth factor receptor (EGFR), C-C Motif Chemokine Ligand 5 (CCL5), transforming growth factor- $\beta 1$ (TGF $\beta 1$ ), and other proteins. PDL may moderate immune system to shorten the course of the disease, delay disease progression and reduce the mortality rate. Conclusion and Implications: We showed the molecular mechanism of PDL treatment for COVID-19. Based on previous studies, PDL was proven to be useful in the treatment of COVID-19 via different levels studies including clinical practice, animal experiments, cell testing, and network pharmacology.
\end{abstract}

\section{Hosted file}

Manuscript-PDL-COVID-19. doc available at https : //authorea.com/users/316498/articles/446644-analysisof-the-molecular-mechanism-of-pudilan-pdl-treatment-for-covid-19

\section{Hosted file}

Figure 1 Workflow.pptx available at https://authorea.com/users/316498/articles/446644-analysisof-the-molecular-mechanism-of-pudilan-pdl-treatment-for-covid-19

\section{Hosted file}

Figure 2 PPI networks.pptx available at https://authorea.com/users/316498/articles/446644-analysisof-the-molecular-mechanism-of-pudilan-pdl-treatment-for-covid-19

\section{Hosted file}

Figure 3 PDL pathways enrichment and effect-2.pptx available at https://authorea.com/users/316498/ articles/446644-analysis-of-the-molecular-mechanism-of-pudilan-pdl-treatment-for-covid-19

\section{Hosted file}


Figure 4 GSEA enrichment.pptx available at https://authorea.com/users/316498/articles/446644analysis-of-the-molecular-mechanism-of-pudilan-pdl-treatment-for-covid-19

\section{Hosted file}

Figure 5 Molecular docking.pptx available at https://authorea.com/users/316498/articles/446644analysis-of-the-molecular-mechanism-of-pudilan-pdl-treatment-for-covid-19 